\title{
Synthesis and characterization of pyridine-3-carboxylic acid hexamolybdochromate $\left(\mathrm{C}_{6} \mathrm{H}_{5} \mathrm{NO}_{2}\right)_{2}\left[\mathrm{H}_{3} \mathrm{O}\right]_{4}\left[\mathrm{CrMo}_{6} \mathrm{O}_{18}(\mathrm{OH})_{6}\right]^{\cdot} \cdot \mathbf{4} \mathrm{H}_{2} \mathrm{O}$
}

\author{
(C) Garry Z. Kaziev, ${ }^{1 *}$ Anna F. Stepnova, ${ }^{1+}$ Van Bang Nguyen, ${ }^{1}$ Viktor N. Khrustalev, ${ }^{2,3}$ \\ Pavel V. Dorovatovsky, ${ }^{3}$ and Saul H. Quenones ${ }^{4}$ \\ ${ }^{1}$ Moscow State Pedagogical University. M. Pirogovskaya St., 1. Moscow, 119571. Russia. \\ stepnova.af@yandex.ru \\ ${ }^{2}$ Peoples' Friendship University of Russia. Miklukho-Maklay St., 6. Moscow, 117198. Russia. \\ ${ }^{3}$ National Research Center "Kurchatov Institute". Ac. Kurchatov Av., 1. Moscow, 123182. Russia. \\ ${ }^{4}$ Universidad Autonoma Metropolitana (Azcapotzalco). San Pablo Ave., 180. D.F. 02200 México.
}

\section{*Supervising author; ${ }^{+}$Corresponding author}

Keywords: polyoxometalates, pyridine-3-carboxylic acid, heteropoly compound, Perloff structure, single-crystal X-ray diffraction.

\begin{abstract}
The Chemistry of heteropoly compounds (HPC) is one of the modern direction of Coordination chemistry. In current times, the high importance in the development of HPC chemistry is the synthesis of new hybrid, organic-inorganic heteropolystructures with preassigned physicochemical properties as well as the determination of common factors of change in these properties depending on the composition and structure. The X-ray diffraction study of the obtained compounds has showed that the packing of molecules into crystals is carried out with the formation of through channels along the $\mathrm{c}$ axis, which can play a significant role, for example, during catalytic processes. The ability of natural nicotinic acid to form complexes with heteropolyanion $\left[\mathrm{CrMo}_{6}(\mathrm{OH})_{6} \mathrm{O}_{18}\right]^{4-}$ is known. The high biological activity of nicotinic acid, as well as the activity of a number of polymetallates to the suppression of certain types of viruses which was described in the literature, make it possible to consider hybrid materials based on these substances promising from the point of view of the consciousness of new pharmaceuticals. Based on this data, we have synthesized pyridine-3carboxylic acid hexamolybdochromate of composition $\left(\mathrm{C}_{6} \mathrm{H}_{5} \mathrm{NO}_{2}\right)_{2}\left[\mathrm{H}_{3} \mathrm{O}\right]_{4}\left[\mathrm{CrMo}_{6} \mathrm{O}_{18}(\mathrm{OH})_{6}\right] 4 \mathrm{H}_{2} \mathrm{O}$. The compound was studied by chemical, X-ray diffraction, thermogravimetric, NMR and IR spectroscopic methods of analysis. It is established that the synthesized compound crystallizes in triclinic syngony with unit cell parameters: $\mathrm{a}=$ $9.1640(8) \AA, \mathrm{b}=10.6441(11) \AA, \mathrm{c}=10.8241(12) \AA ; \alpha=95.968(10)^{\circ}, \beta=109.864(12)^{\circ}, \gamma=105.059(11)^{\circ} ; \rho_{\text {calc }}$ $=2.502 \mathrm{~g} / \mathrm{cm}^{3}, \mathrm{~V}=937.2(2) \AA^{3} ; \mathrm{Z}=1$.
\end{abstract}

\section{References}

[1] S.H. Quenones, G.Z. Kaziev, Yu.S. Vlasov, A.V. Oreshkina, O.A. Kirichenko, A.M. Koroteev. Synthesis and physicochemical study of hexamolybdenochromate diazabicycloundecene $\left[\mathrm{C}_{9} \mathrm{H}_{16} \mathrm{~N}_{2}\right] \mathrm{H}_{3}\left[\mathrm{CrMo}_{6} \mathrm{O}_{18}(\mathrm{OH})_{6}\right] \cdot 2 \mathrm{H}_{2} \mathrm{O}$. Journal of Inorganic Chemistry. 2014. Vol.59. No.5. P.637-640. DOI: $10.7868 / \mathrm{S} 0044457 \mathrm{X} 14050134$

[2] Yuan S, Feng L, Wang K, Pang J, Bosch M, Lollar C, Sun Y, Qin J, Yang X, Zhang P, Wang Q, Zou L, Zhang Y, Zhang L, Fang Y, Li J, Zhou H.C. Stable Metal-Organic Frameworks: Design, Synthesis, and Applications. Adv Mater. 2018 Sep;30(37):e1704303. DOI: 10.1002/adma.201704303.

[3] V.S. Sergienko, M.A. Porai-Koshits. Results of science and technology. Ser. crystal chemistry. Vol.19. Moscow: VINITI. 1985. P.79. (russian)

[4] Kaziev G.Z., Karamnov M.A., S. Olgin Quenones et al. J. of Inorg. Chem. 2003. Vol.48. No.5. P.782. (russian)

[5] A.V. Oreshkina, G.Z. Kaziev, A.V. Steblevsky, S. Holgin Quenones, A. de Ita, O.N. Peretokina. Synthesis and physico-chemical study of nonamolybdomanganate with cadmium-ammonia cation. Journal of Inorg Chemistry. 2013. Vol.58. No.5. P.585-587. (russian)

[6] G.Z. Kaziev, O.A. Kirichenko, A.I. Stash, S.H. Quenones, E.A. Solovieva, Chen Yu. Synthesis and study of acid dodecavungstate phosphate pyridine 3-carboxylic acid composition of $\left(\mathrm{C}_{6} \mathrm{NO}_{2} \mathrm{H}_{5}\right)_{2} \mathrm{H}\left[\mathrm{PW}_{12} \mathrm{O}_{40}\right] \cdot 2 \mathrm{H}_{2} \mathrm{O}$. Journal of Structural Chemistry. 2014. Vol.55. No.4. P.708-715. (russian) 
SYNTHESIS AND CHARACTERIZATION OF PYRIDINE-3-CARBOXYLIC ACID HEXAMOLYBDOCHROMATE ... 50-55

[7] G.Z. Kaziev, O.A. Kirichenko, A.F. Stepnova, H. Saul. Quinones, Morales Sanchez L. A. Nguyen Van Bang. Synthesis and study of acid dodecatungstate borate pyridine-3-carboxylic acid composition $\left(\mathrm{C}_{6} \mathrm{NO}_{2} \mathrm{H}_{6}\right)_{2} \mathrm{H}_{3}\left[\mathrm{BW}_{12} \mathrm{O}_{40}\right] \cdot 2 \mathrm{H}_{2} \mathrm{O}$. Sciences of Europe. 2016. Vol.5. No.5. P.100-105. (russian)

[8] T.G.G. Battye, L. Kontogiannis, O. Johnson, H.R. Powell, A.G.W. Leslie. Acta Cryst. 2011. D67. P.271-281.

[9] P.R. Evans. Acta Cryst. 2005. D62. P.72-82.

[10] G.M. Sheldrick. Acta Cryst. 2015. C71. P.3-8.

[11] R.Sh. Zatrudina, K.S. Ivina. IR Spectrum of $\beta$-pyridinecarboxylic amide. Bulletin of the Volgograd state. un-that. Ser 1. Mat. 2012. No.2 (17). P.78-82. (russian)

[12] K. Nakamoto. IR spectra of inorganic compounds. Moscow: World. 1966. 411p. (russian) 